\title{
Antimicrobial susceptibility and pathogenicity of Escherichia coli strains of environmental origin
}

\author{
Suscetibilidade antimicrobiana e patogenicidade de amostras de \\ Escherichia coli de origem ambiental
}

\begin{abstract}
Daiane Carvalho $^{\mathrm{I}}$ Fabrine Finkler $^{\mathrm{I}}$ Tiela Trapp Grassotti $^{\mathrm{I}}$ Hiran Castagnino Kunert Filho Francisco Esmaile de Sales Lima ${ }^{I}$ Beatriz Dugaich Soares ${ }^{I}$ Juliana Marzari Rossato $^{\mathrm{I}}$ Augusto César da Cunha ${ }^{\mathrm{I}}$ Kelly Cristina Tagliari de Brito ${ }^{\mathrm{I}}$ Benito Guimarães de Brito ${ }^{\mathrm{I}}$
\end{abstract}

\section{ABSTRACT}

The study aimed to evaluate the antimicrobial susceptibility of 109 samples of Escherichia coli $(\boldsymbol{E}$. coli) of environmental origin and to characterize these isolates according to the degree of pathogenicity in vivo, verifying a possible relationship between this variable and susceptibility to the active principles tested. The isolates were subjected to disc diffusion test to 14 antibiotics. From $16.5 \%$ to $90 \%$ of the samples were sensitive; 1 - $28.5 \%$ showed intermediate degree of susceptibility and between 9 to $78 \%$ of $\boldsymbol{E}$. coli analyzed were resistant. The highest resistance percentages were seen in the class of quinolones and tetracyclines (>75\%), and for sensitivity in the class of amphenicols (68.8\%). By inoculating 1- day - old chicks, the isolates were classified as highly pathogenic (2.7\%), intermediate (10.1\%), low $(42.2 \%)$ and apathogenic (45\%). It was observed a wide variation in the susceptibility profile of isolates in relation to antimicrobials. It was also found that most of the samples had pathogenic potential (55\%), thus being considered as APEC (avian pathogenic $\boldsymbol{E}$. coli). No relationship between pathogenicity and antimicrobial susceptibility $(P \leq 0.05)$ was observed.

Key words: Escherichia coli, resistance, antimicrobials, pathogenicity, poultry.

\section{RESUMO}

O estudo teve como objetivo avaliar a suscetibilidade antimicrobiana de 109 amostras de Escherichia coli (E. coli) de origem ambiental frente a antibióticos e caracterizar esses isolados quanto ao grau de patogenicidade in vivo, verificandose uma possivel relação entre esta variável e a suscetibilidade aos princípios ativos testados. Os isolados foram submetidos ao teste de disco-difusão para 14 antibióticos. Entre $16.5 \%$ a $90 \%$ das amostras foram sensiveis, 1-28.5\% apresentaram grau de suscetibilidade intermediário e entre $9-78 \%$ das $\boldsymbol{E}$. coli analisadas foram resistentes. Os maiores percentuais de resistencia foram encontrados para a classe das quinolonas e das tetraciclinas (>75\%), e de sensibilidade para a classe dos anfenicóis (68.8\%). Por meio da inoculação em pintinhos de um dia de idade, os isolados foram classificados como sendo de patogenicidade alta (2.7\%), intermediária (10.1\%), baixa (42.2\%) e apatogênicos (45\%). Foi observada uma ampla variação no perfil de suscetibilidade das amostras frente aos antimicrobianos. Verificou-se também que a maioria apresentou potencial patogênico (55\%), sendo, portanto, consideradas APEC (E. coli patogênica para aves). Não foi observada relação entre a patogenicidade e a suscetibilidade aos antimicrobianos $(P \leq 0.05)$.

Palavras-chave: Escherichia coli, resistência, antimicrobianos, patogenicidade, avicultura.

\section{INTRODUCTION}

The $\boldsymbol{E}$. coli is a normal inhabitant of the gastrointestinal tract of mammals and birds. This microorganism is a Gram negative bacterium, within the family Enterobacteriaceae, and able to grow under aerobic and anaerobic conditions (BARNES et al., 2008). It is assumed that approximately $10^{6} \boldsymbol{E}$. coli $\mathrm{CFU}$ per gram of feces might be detected in the aviaries, making it practically impossible to be eliminated from poultry environment (GROSS, 1994). Of this total, between 10 to 20 percent could be potentially pathogenic, excreted in the feces and, then contaminating the environment (FERREIRA \& KNÖBL, 2009).

The $\boldsymbol{E}$. coli strains that can play an important role on avian diseases are collectively

\footnotetext{
'Laboratório de Saúde das Aves \& Inovação Tecnológica, Instituto de Pesquisas Veterinárias Desidério Finamor (IPVDF), Fundação Estadual de Pesquisa Agropecuária (FEPAGRO), 92990-000, Eldorado do Sul, RS, Brasil. E-mail: benitobrito@gmail.com. ${ }^{*}$ Corresponding author. 
denominated APEC. It is believed that only specific strains of $\boldsymbol{E}$. coli are virulent, thus triggering the onset of the disease (DELICATO et al., 2003), resulting in local or systemic infection, referred, generally, as avian colibacillosis (FERREIRA \& KNÖBL, 2009).

In order to reduce mortality associated to avian colibacillosis, the preventive use of antimicrobials is one of the measures used to minimize the economic impact caused by $\boldsymbol{E}$. coli (CHAUVIN et al., 2007). However, this pathogen is becoming increasingly resistant, a fact that has generated great concern in the poultry industry over the years (PESSANHA \& GONTIJO FILHO, 2001; ZANATTA et al., 2004; SMITH et al., 2007). One of the reasons for the increased resistance is the antibiotic therapy for colibacillosis, which does not result in recovery of the birds before slaughter and further exacerbates the problem of colibacillosis, as well as other bacterial diseases. The avian $\boldsymbol{E}$. coli are frequently multi-drug resistant and the practice of indiscriminate use of antimicrobials in poultry industry is the most important factor to promote selection and dissemination of drug resistant microorganisms (GYLES, 2008).

The phylogenetic relationships found among ExPEC (Extraintestinal pathogenic E. coli) APEC, UPEC (Uropathogenic $\boldsymbol{E}$. coli) and NMEC (Newborn meningitis-causing $\boldsymbol{E}$. coli) strains highlight the zoonotic potential of strains of avian origin (JOHNSON et al., 2007). Thus, the study of antimicrobial susceptibility of these isolates becomes an important health public issue.

About the pathogenicity of $\boldsymbol{E}$. coli, inoculation assays using chicks have been performed in order to evaluate the in vivo expression of virulence factors of APEC (SOUZA, 2010; BARBIERI et al., 2012; BARBIERI et al., 2013). Nevertheless, there are few studies correlating the degree of pathogenicity of the microorganism to the findings of resistance or sensitivity to antimicrobial agents, especially when it comes to samples of environmental origin.

In this context, the present study aimed to evaluate the antimicrobial susceptibility profile of $\boldsymbol{E}$. coli isolated from broiler houses, as well as to characterize the isolates concerning their degree of pathogenicity in vivo, in order to investigate a possible relationship between these two variables.

\section{MATERIAL AND METHODS}

Sample collection and laboratory processing During November 2011 and April 2012, overshoe swab samples from broiler houses in Rio
Grande do Sul state were processed in the Poultry Health Laboratory \&Technological Innovation of the Instituto de Pesquisas Veterinárias Desidério Finamor (IPVDF). Sterile boot socks were put over the shoes and collectors walked throughout a large area of the broiler houses. Later, the boot socks were placed inside sterile bags, sealed, identified and stored in cool boxes. Sample bags were sent to laboratory after collection.

When samples arrived at the laboratory, $225 \mathrm{~mL}$ buffered peptone water were added to each plastic bag and incubated for $18-24$ hours at $37^{\circ} \mathrm{C}$. After this, each culture was streaked in MacConkey Agar (MAC) plates and then, incubated under the same conditions described previously. Colonies suspected to be $\boldsymbol{E}$. coli (lactose positive) were reisolated on MAC and submitted to biochemical test to confirm the genus Escherichia (lysine decarboxylase test, Simmon's cytrate, sulphite indol mobility, triple sugar iron, urea hydrolysis), as proposed by MARTINEZ \& TRABULSI (2008). Altogether, 109 E. coli samples were isolated, each one coming from a single broiler house.

\section{Antimicrobial susceptibility assay}

All the E.coli isolates $(n=109)$, were submitted to the disc diffusion test according to the Clinical and Laboratory Standards Institute guidelines (CLSI, 2012), using $\boldsymbol{E}$. coli strain ATCC 25922 as a control. The antimicrobial agents tested were: neomycin $(30 \mu \mathrm{g})$, enrofloxacin $(5 \mu \mathrm{g})$, florfenicol $(30 \mu \mathrm{g})$, ciprofloxacin $(5 \mu \mathrm{g})$, tetracycline $(30 \mu \mathrm{g})$, gentamicin $(10 \mu \mathrm{g})$, nalidixic acid $(30 \mu \mathrm{g})$, doxycycline $(30 \mu \mathrm{g})$, nitrofurantoin $(300 \mu \mathrm{g})$, chloramphenicol $(30 \mu \mathrm{g})$, sulphonamide $(300 \mu \mathrm{g})$ norflaxocin $(10 \mu \mathrm{g})$, ampicillin $(10 \mu \mathrm{g})$ and trimethoprim-sulphonamide combinations $(25 \mu \mathrm{g})$. The interpretation categorized each result as sensitive, intermediate or resistant. For each E. coli isolate, Multiple Antibiotic Resistance (MAR) Index was calculated as the number of antimicrobials to which test isolate displayed resistance divided by total number of antimicrobials to which the test organism has been evaluated for sensitivity (KRUMPERMAN, 1983).

In vivo pathogenic evaluation

Groups of 10 1-day-old chicks were inoculated subcutaneously with $0.1 \mathrm{~mL}\left(\sim 1.5 \times 10^{7}\right.$ CFU) of an overnight culture (a McFarland 0.5 standard suspension) containing $\sim 1.5 \times 10^{8} \mathrm{CFU} \mathrm{\textrm {mL } ^ { - 1 }}$ of each isolate. A control group was inoculated with BHI (brain heart infusion) broth. The animals were observed over five days, assessing the lethality rate, 
in order to classify the bacterial strains as being apathogenic (absence of lethality), low $(<50 \%$ of lethality), intermediate $(\geq 50-<80 \%$ of lethality) or of high virulence $(\geq 80 \%$ of lethality). Chick deaths by $\boldsymbol{E}$. coli were confirmed after postmortem examinations looking for gross lesions related to colibacillosis (airsacculitis, pericarditis, perihepatitis, peritonitis and/or cellulitis). APEC isolates were considered to be those capable to cause lethality of, at least, one bird within the group.

Statistical analysis

Student's t-test was used to verify differences among MAR mean values of groups classified, according to their pathogenicity scores. In order to check a possible relationship between pathogenicity and resistance/sensibility to the antimicrobials analyzed, the Chi-square test $\left(\chi^{2}\right)$ was carried out. All statistical analysis was performed with the Statistical Package for the Social Sciences (IBM SPSS v.18) and statistical significance was accepted at $\mathrm{P} \leq 0.05$.

\section{RESULTS}

Antibiotic resistance among the isolates

The susceptibility profile of all 109

$\boldsymbol{E}$. coli isolates to antimicrobial agents is shown in figure 1A. With the exception of two isolates, the others were resistant to, at least, one of the antimicrobials. About $42 \%$ of the isolates showed MAR index ranging from 0.25-0.5 (resistance from 4 to 7 antimicrobials); $21 \%$ with an MAR index of $0-0.25$ (resistance to 3 antimicrobials) and only $5.5 \%$ showing MAR $>0.75$ (resistance to more than 11 antimicrobials). There was no isolate resistant to all of the antimicrobials tested.

When analyzing the classification by chemical group (Figure 1B), it was observed that more than $75 \%$ of the isolates were resistant to the tetracycline and quinolone groups. Nonetheless, this percentage drops to $3.7 \%$ and $0.9 \%$ when excluding nalidixic acid and tetracycline, respectively. Overall, multi-resistance patterns were present in approximately $91 \%$ of the $\boldsymbol{E}$. coli isolates. Regarding the sensibility, the greatest percentages were observed in the amphenicols class $(68.8 \%)$.

Concerning the sites of antibiotic action (Figure 1C), more than $70 \%$ were resistant to, at least, one of the antimicrobials that block or inhibit protein synthesis (gentamicin, neomycin, tetracycline, doxycycline, chloramphenicol, florfenicol); nucleic acid synthesis (enrofloxacin, norfloxacin, ciprofloxacin and nalidixic acid); and folate synthesis (sulphonamide and trimethoprimsulphonamide combinations). Nitrofurantoin, a drug with a broad mechanism of action, presented the highest percentage of sensibility $(47.7 \%)$.

Pathogenicity tests

Table 1 shows the classification of the $109 \boldsymbol{E}$. coli isolates according to their pathogenicity index calculated from the lethality percentages in 1-day-old chicks. It was observed that more than $87.2 \%$ of the isolates were classified as low pathogenic and apathogenic strains. Only $10.1 \%$ and $2.7 \%$ of the isolates presented intermediate and high pathogenicity, respectively.

Pathogenicity versus antimicrobial susceptibility Apart from the three isolates classified as high pathogenic, the other ones presented antibiotic resistance superior to $78 \%$ against quinolones. All of the highly pathogenic strains were resistant to at least one antimicrobial belonging to the beta-lactam and sulphonamides classes; however, the sensitivity was $100 \%$ regarding nitrofurans. All groups showed levels of resistance for tetracycline $(>65 \%)$, amphenicols (20-67\%), trimethoprim - sulphonamide (39-67\%). Only the isolates of intermediate pathogenicity had resistance superior to $70 \%$ for aminoglycosides, whereas in the isolates from other groups, the resistance did not exceed the rate of $48 \%$ for this class of antimicrobial.

In relation to MAR indices, no statistical differences were observed, as values ranged from 0.42 to 0.46 (Table 1) among the different groups of pathogenicity. Grouping the strains in pathogenic (high, intermediate and low) and apathogenic, as well as excluding samples with intermediate degree of susceptibility to antibiotics, no statistically significant relationship was observed between variables pathogenicity and sensitivity/resistance to the antimicrobials tested.

\section{DISCUSSION}

There was a wide variation in susceptibility profiles among the 109 isolates of $\boldsymbol{E}$. coli to the 14 antimicrobials tested. Between $16.5 \%$ and $90 \%$ of the isolates were sensitive; 1 to $28.5 \%$ of the isolates showed intermediate degree of susceptibility and among 9 to $78 \%$ of $\boldsymbol{E}$. coli analyzed were resistant.

The highest levels of resistance were found for nalidixic acid and tetracycline. These findings were also reported by other authors (PESSANHA \& 


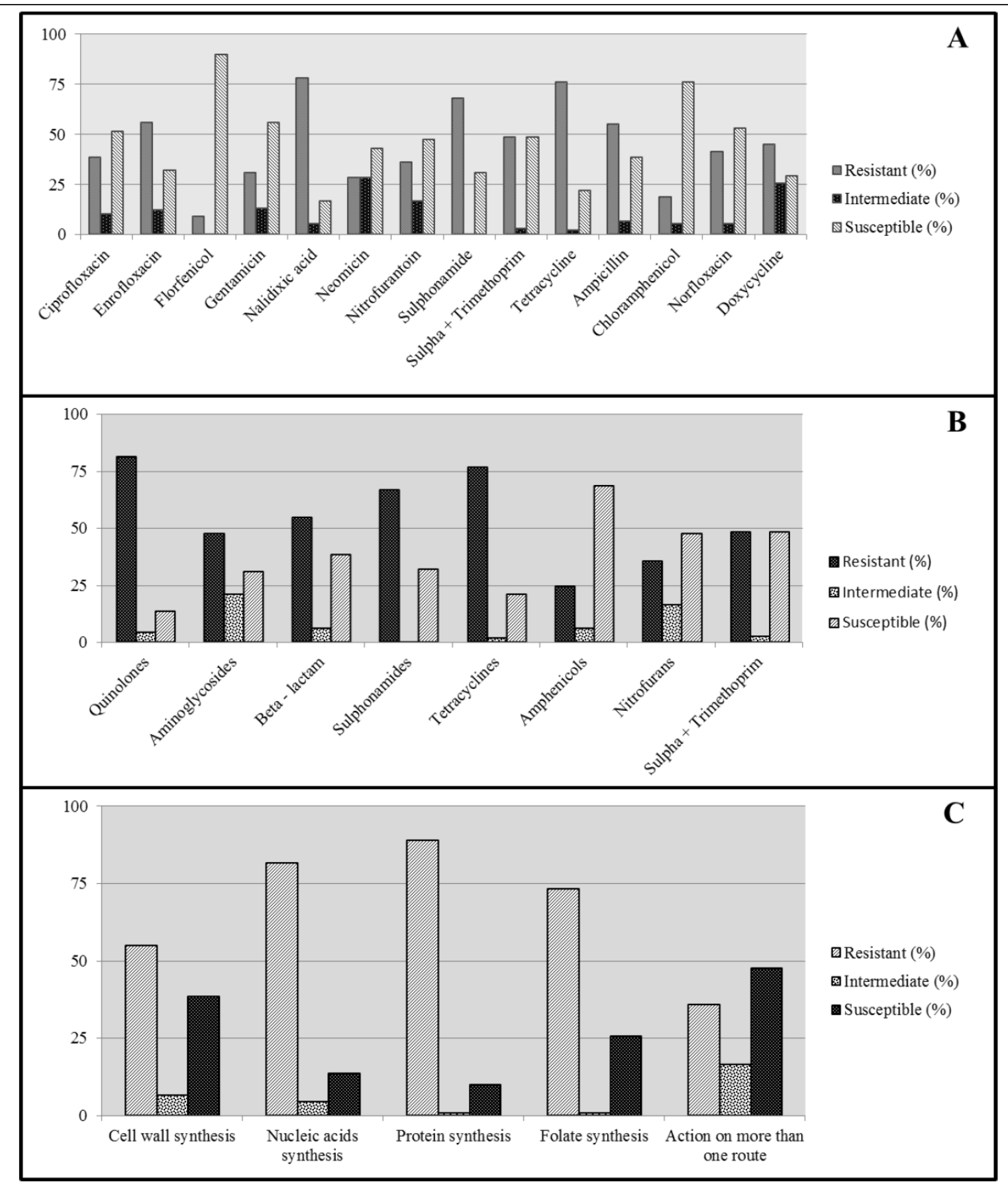

Figure 1 - A: classification of $109 \boldsymbol{E}$. coli isolates, according to their susceptibility to the 14 antimicrobials tested. B: according to their susceptibility to different classes of antimicrobials. C: according to their susceptibility to different antimicrobials grouped by the action mechanism.

GONTIJO FILHO, 2001; ZANATTA et al., 2004). These results reflect the high levels of resistance found in the class of drugs that act by inhibiting protein and nucleic acids synthesis, encompassing tetracycline and nalidixic acid, respectively.
As reported by MARIETTO GONÇALVES \& ANDREATTI FILHO (2010), the low sensitivity to these active principles can be explained, in part, because they have a low cost and are easily obtained, which leads to an indiscriminate and incorrect use 
Table 1 - Classification of $109 \boldsymbol{E}$. coli samples according to the pathogenicity index and MAR mean values obtained for the different antimicrobials.

\begin{tabular}{lcc}
\hline Pathogenicity index (\% lethality) & Samples $(\%)$ & MAR \\
\hline High $(>80)$ & 2.7 & $0.44^{\mathrm{a}}$ \\
Intermediate $(=50-<80)$ & 10.1 & $0.42^{\mathrm{a}}$ \\
Low $(<50)$ & 42.2 & $0.42^{\mathrm{a}}$ \\
Apathogenic $(0)$ & 45 & $0.46^{\mathrm{a}}$ \\
\hline
\end{tabular}

Indicated mean values using the same letter do not differ $(\mathrm{P}=0.05)$.

of antimicrobial drugs. According to KHAN et al. (2014) the use of tetracyclines with therapeutic purpose in poultry production is very common, which is generating a significant increase in resistance findings. SILVA \& HOLLENBACH (2010) claim that susceptibility reduction to quinolones has been observed frequently in different areas of veterinary medicine, mainly for the first generation drugs, as in the case of nalidixic acid. The class of amphenicols and nitrofurans obtained the highest percentages of sensitivity among all antimicrobials tested. This result is possibly due to the banning of these classes as a food additive and for therapeutic purposes in Brazil since 2003 (BRASIL, 2003).

It was noted that no antibiotic was $100 \%$ effective, with most of the isolates (91\%) presenting multidrug - resistance, even in the case of environmental samples, which, in theory, was expected a greater sensitivity. These findings reflect at MAR indices, being that most of the samples were resistant to four or more antimicrobials. CHINWE et al. (2014), when assessing $\boldsymbol{E}$. coli samples isolated from birds, also reported high levels of resistance in samples of environmental origin. The multidrug resistance's feature has been observed in $\boldsymbol{E}$. coli samples from avian origin in Brazil and other American countries (ZANATTA et al., 2004; SMITH et al., 2007), as well as in Europe (GUERRA et al., 2003), Asia (SAHOO et al., 2012), Africa (OGUNLEYE et al., 2008) and Oceania (INGRAM et al., 2011). This fact demonstrates that the use of antimicrobials in poultry industry over the years has increasingly been favoring the emergence of resistant isolates. According to PESSANHA \& GONTIJO FILHO (2001), broilers can act as reservoirs of important antibiotic resistance genes in veterinary and human medicine and the use of growth promoters in animal feed may contribute to the occurrence of multidrug - resistant isolates as well.

Regarding pathogenicity, it was noted that despite being of environmental origin samples, more than $50 \%$ of them were pathogenic to a lesser or greater degree, therefore, being regarded as APEC. This finding is in contrast with data from FERREIRA \& KNÖBL (2009), which consider that within $\boldsymbol{E}$. coli of environmental origin; only 10 to $20 \%$ are pathogenic. In this study, it was also observed that the pathogenicity of the samples did not interfere on the results of susceptibility to antimicrobials. Hence, the pathogenicity of a sample cannot be considered as primary factor for resistance or sensitivity to a particular drug, under the conditions of this study. Pathogenicity, as well as the high levels of antimicrobial resistance can be explained, likely, by the exchange of genetic material between different bacterial strains, where genes involved in virulence and resistance are constantly transferred, mostly mediated by plasmids. As reported by FLORIAN FRICKE et al. (2009), a single plasmid can possess genes responsible for both antimicrobial resistance and pathogenicity of APEC isolates. The transfer of genetic elements leads an apathogenic strain to present some pathogenic potential and, similarly, isolates that are sensitive to certain antimicrobials can become resistant.

\section{CONCLUSION}

There was a large variation in the antimicrobial susceptibility profiles tested. The highest levels of resistance were found for tetracycline and nalidixic acid, as well as the largest percentage of sensitivity for amphenicols. Concerning the pathogenicity, most of the samples presented some pathogenic potential, but this variable had no influence on the degree of susceptibility of $\boldsymbol{E}$. coli regarding the antimicrobials tested.

\section{ACKNOWLEDGEMENTS}

To Conselho Nacional de Desenvolvimento Científico e Tecnológico (CNPq) (Proc 458299/2012-0; 312126/2013-1; 578440/2008-3/6-2009 552584; 314311/2009-2), Financiadora de Estudos e Projetos (FINEP) (proc. 01100783.00), Fundação de Amparo à Pesquisa do Estado do Rio Grande do Sul (FAPERGS) (1066-2551/13-0) by granting scholarships and financial support.

\section{REFERENCES}

BARBIERI, N.L. et al. Characterization of extra-intestinal Escherichia coli isolated from a peacock (Pavocristatus) with colisepticemia. Avian Diseases, v.56, p.436-440, 2012. Available from: <http://www.bioone.org/doi/abs/10.1637/10116992112-DIGEST.1>. Accessed: may, 15, 2014. doi: 10.1637/10116-992112-DIGEST.1.

BARBIERI, N.L. et al. Genotypes and pathogenicity of cellulitis isolates reveal traits that modulate APEC virulence. Plos One, v.8, 
p.e72322, 2013. Available from: <http://www.plosone.org/article/ fetchObject.action?uri=info\%3Adoi\%2F $10.1371 \% 2$ Fjournal.pon e.0072322\&representation $=P D F>$. Accessed: may, 15, 2014. doi: 10.1371/journal.pone.0072322.

BARNES, H.J. et al. Colibacillosis. In: CALNEK, B.D. Diseases of poultry. 12.ed. ISU Press: Ames, 2008. p.691-738.

BRASIL. Instrução Normativa no․ 09 de 27 de junho de 2003. Ministério da Agricultura Pecuária e Abastecimento. Available from: <http://www.agricultura.gov.br>. Accessed: aug. 14, 2014.

CHAUVIN, C. et al. Time - patterns of antibiotic exposure in poultry production - a Markov chains exploratory study of nature and consequences. Preventive Veterinary Medicine, v.80, p.230240, 2007. Available from: <http://www.sciencedirect.com/ science/article/pii/S0167587707000530>. Accessed: may, 15, 2014. doi: 10.1016/j.prevetmed.2007.02.010.

CHINWE, N. et al. Cloacal fecal carriage and occurrence of antibiotic resistant Escherichia coli in chicken grown with and without antibiotic supplemented feed. Journal of Veterinary Medicine and Animal Health, v.6, p.91-94, 2014. Available from: $<$ http://www.academicjournals.org/JVMAH > . Accessed: may, 15, 2014. doi: 10.5897/JVMAH2013.0267.

CLSI. Performance standards for antimicrobial susceptibility testing. 15.ed. Wayne, PA, 2012. (Document M100-S22, TwentySecondy Informational Supplement).

DELICATO. E.R. et al. Virulence-associated genes in Escherichia coli isolates from poultry with colibacillosis. Veterinary Microbiology, v.94, p.97-103, 2003. Available from: <http:// www.sciencedirect.com/science/article/pii/S0378113503000762>. Accessed: may, 15, 2014. doi: 10.1016/S0378-1135(03)00076-2.

KHAN, M.S. et al. Isolation and Identification of non-plasmid Multidrug Resistant Escherichia coli from poultry wastes in Chittagong Region, Bangladesh. Journal Bacteriology \& Parasitology, v.5, p.1-7, 2014. Available from: $<$ http://omicsonline. org/open-access/isolation-and-identification-of-nonplasmidmultidrug-resistant-ecoli-from-poultry-wastes-in-chittagongregion-21559597.1000182.php?aid=23316>. Accessed: may, 1, 2014. doi: $10.4172 / 2155-9597.1000182$.

FERREIRA, A.J.; KNÖBL, T. Colibacilose aviária. In: BERCHIERI JÚNIOR, A. Doenças das aves. Campinas: Fundação APINCO de Ciência e Tecnologia Avícola, 2009. p.197-205.

FLORIAN FRICKE, W. et al. Antimicrobial resistanceconferring plasmids with similarity to virulence plasmids from avian pathogenic Escherichia coli strains in Salmonella enterica serovar Kentucky isolates from poultry. Applied and Environmental Microbiology, v.75, p.5963-5971, 2009. Available from: <http://www.ncbi.nlm.nih.gov/pmc/articles/ PMC2747853/pdf/0786-09.pdf $>$. Accessed: may, 15, 2014. doi: 10.1128/AEM.00786-09.

GROSS, W.G. Disease due to Escherichia coli in poultry. In: GYLES, C.L. Escherichia coli in domestic animals and humans. Wallingford: CAB International, 1994. p.237-259.

GUERRA, B. et al. Phenotypic and genotypic characterization of antimicrobial resistance in German Escherichia coli isolates from cattle, swine and poultry. Journal of Antimicrobial
Chemotherapy, v.52, p.489-492, 2003. Available from: <http:// jac.oxfordjournals.org/content/52/3/489.full.pdf $>$. Accessed: may, 15, 2014. doi: $10.1093 / \mathrm{jac} / \mathrm{dkg} 362$.

GYLES, C. Antimicrobial resistance in selected bacteria from poultry. Animal Health Research Reviews, v.9, p.149158, 2008. Available from: <http://www.ncbi.nlm.nih.gov/ pubmed/19102788>. Accessed: may, 15, 2014. doi: 10.1017/ S1466252308001552.

INGRAM, P.R. et al. Antibiotic non-susceptible $\boldsymbol{E}$. coli in retail poultry samples from Western Australia. In: AUSTRALIAN SOCIETY FOR ANTIMICROBIALS ANNUAL SCIENTIFIC MEETING, 12., 2011. Melbourne: Proceedings... Melbourne, Vic, Australia, 2011. p.24-26.

JOHNSON, T.J. et al. The genome sequence of avian pathogenic Escherichia colistrain $\mathrm{O} 1: \mathrm{K} 1: \mathrm{H} 7$ shares strong similarities with human extraintestinal pathogenic Escherichia coligenomes. Journal Bacteriology, v.189, p.3228-3236, 2007.

KRUMPERMAN, P.H. Multiple antibiotic resistance indexing of Escherichia coli to identify high - risk sources of fecal contamination of foods. Applied and Environmental Microbiology, v.46, p.165170, 1983. Available from: <http://aem.asm.org/content/46/1/165. full.pdf + html $>$. Accessed: may, 15, 2014.

MARIETTO GONCALVES, G.A.; ANDREATTI FILHO, R.L. Suscetibilidade antimicrobiana de amostras de Escherichia coli isoladas de frango industrial (Gallus gallus domesticus- Linnaeus, 1758) com colibacilose. Comunicação Científica. Arquivos do Instituto Biológico, v.77, p.715-718, 2010. Available from: $<$ http://www.biologico.sp.gov.br/docs/arq/v77_4/marietto.pdf $>$. Accessed: may, 15, 2014.

MARTINEZ, M.B.; TRABULSI, L.R. Enterobacteriaceae. In: TRABULSI, L.R.; ALTERHUM, F. Microbiologia. 5.ed. Rio de Janeiro: Guanabara-Koogan, 2008. p.271-279.

OGUNLEYE, A.O. et al. Multidrug resistant Escherichia coli isolates of poultry origin in Abeokuta, South Western Nigeria. Veterinarski Arhiv, v.78, p.501-509, 2008. Available from: $<$ http://unaab.edu.ng/publications-abstract/Sonibare5.pdf $>$. Accessed: may, 15, 2014.

PESSANHA, R.P.; GONTIJO FILHO, P.P. Uso de antimicrobianos como promotores de crescimento e resistência em isolados de Escherichia coli e de Enterobacteriaceae lactose-negativa da microflora fecal de frangos de corte. Arquivo Brasileiro de Medicina Veterinária e Zootecnia, v.53, p.111-115, 2001. Available from: <http://www.scielo.br/scielo.php?pid=S0102$09352001000100018 \&$ script $=$ sci arttext $>$. Accessed: may, 15, 2014. doi: 10.1590/S0102-09352001000100018.

SAHOO, T.K. et al. Prevalence, isolation, characterisation and antibiogram study of pathogenic Escherichia coli from different poultry farms of Odisha. Journal of Advanced Veterinary Research, v.2, p.169-172, 2012. Available from: <http://www. advetresearch.com/index.php/avr/article/view/98/60>. Accessed: may, 15, 2014

SILVA, J.M.B.; HOLLENBACH, C.B. Fluoroquinolonas $\mathrm{x}$ resistência bacteriana na medicina veterinária. Artigo de revisão. Arquivos do Instituto Biológico, v.77, p.363-369, 2010. Available from:<http://www.biologico.sp.gov.br/docs/arq/v77 2/silva1. pdf $>$. Accessed: 15, may, 2014. 
SMITH, J.L. et al. Impact of antimicrobial usage on antimicrobial resistance in commensal Escherichia colistrains colonizing broiler chickens. Apllied and Environmental Microbiology, v.73, p.1404-1414, 2007. Available from: <http://www.ncbi.nlm. nih.gov/pmc/articles/PMC1828781/pdf/1193-06.pdf>. Accessed: may, 15, 2014. doi: 10.1128/AEM.01193-06.

SOUZA, G.F. Estabelecimento de um novo índice de patogenicidade para cepas de Escherichia colie uso de redes neurais artificiais. 2010. p.103. Tese (Doutorado em Ciências Veterinárias) - Universidade Federal do Rio Grande do Sul, Porto Alegre, RS.

ZANATTA, G.F. et al. Suscetibilidade de amostras de Escherichia coli de origem aviária a antimicrobianos. Arquivos do Instituto Biológico, v.71, p.283-286, 2004. Available from: <http://www. biologico.sp.gov.br/docs/arq/V71_3/zanatta.PDF $>$. Accessed: may, 15, 2014. 